PII: S0271-5317(00)00138-X

\title{
ANTIOXIDANTS AND DISEASE: MORE QUESTIONS THAN ANSWERS
}

\author{
Norman J. Temple, $\mathrm{PhD}^{1,2}$ \\ Athabasca University, Athabasca, Alberta T9S 3A3, Canada
}

\begin{abstract}
Reactive oxygen species are widely believed to be involved in the etiology of many diseases as indicated by the signs of oxidative stress seen in those discases. Conversely, antioxidants are believed to be protective. An important part of the supporting evidence is the consistently-seen inverse association between, on the one hand, intake of $B$-carotene and vitamin $C$ and of fruit and vegetables, and, on the other hand, risk of cancer and coronary heart disease (CHD). However, the failure of supplemental $\beta$-carotene to prevent these diseases in intervention trials suggests that the associations for that nutrient reflect confounding rather than cause and effect. With respect to other antioxidants there is inconsistent evidence that supplements of vitamin $\mathrm{E}$ may have some ability to prevent cancer and CHD while selenium may prevent cancer. Overall, the role of oxidative stress in disease, especially cancer and CHD, has probably been overstated; other components of the diet (other nutrients, phytochemicals and dietary fiber) likely play a significantly greater role. The possible benefits of supplements are discussed.

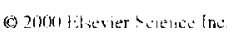

Key Words: Antioxidant, Cancer, Coronary Disease, Oxidative Stress, Vitamin E

\section{INTRODUCTION}

Various evidence indicates that oxidative stress is closely associated with a diverse assortment of diseases (1). From this it is generally inferred that antioxidants will therefore prevent those diseases. The evidence is re-evaluated.

In this paper a nutrient refers to any substance which is essential (such as a vitamin) while a phytochemical is a plant-based substance which may have a beneficial effect in the body but is nonessential. Antioxidants may be in either class. For instance, $\beta$-carotene is a nutrient whereas various other carotenoids also act as antioxidants but do not have vitamin A activity and are therefore not

1. Work carried out at the CDL Programme, Medical Research Council, Cape Town, South Africa.

2. Email: normant@athabascau.ca. Fax (780)6756186 
essential nutrients but phytochemicals.

\section{THE BIOCHEMISTRY OF OXIDATIVE STRESS}

$\Lambda t$ a meeting of the World Health Organisation in the mid-1960s the Russian toxicologist, Professor Sanojki, referred to various degenerative diseases as being "rusting diseases" and linked their etiology to reactive oxygen species (ROS) (2).

The biochemistry of ROS and oxidative stress has been reviewed elsewhere (3-5). ROS include singlet oxygen, the superoxide anion radical, the peroxide anion, and the hydroxyl radical. They are highly reactive free radicals produced from molecular oxygen. They can be generated during normal cellular respiration, by activated leucocytes as part of the immune response, and by exogenous oxidants such as air pollution and cigarette smoke. They have an undoubted capability to be harmful by their action on vital cellular components including lipids, proteins and DNA.

The body has several defence systems to counteract oxidative stress. These comprise endogenous enzymes (including catalase, glutathione reductase and superoxide dismutase), endogenous factors (including glutathione, urate and coenzyme Q), and nutritional factors (principally the antioxidant nutrients, especially $\beta$-carotene and other carotenoids, vitamin $\mathrm{C}$, vitamin $\mathrm{E}$ and selenium)

\section{OXIDATIVE STRESS AND DISEASE}

The body is normally in a steady state condition with free radicals being continuously generated and quenched. However, the accumulated long-term damage done by free radicals is implicated in numerous degenerative diseases. Evidence from many has heavily implicated oxidative stress in a spectrum of diseases and of states of body dysfunction. Oxidative stress has been shown variously as depressed levels of antioxidant substances (e.g., vitamin E, urate), low levels of enzymes which form part of the antioxidant defence system, and increased levels of oxidation products (e.g., malondialdehyde, DNA damage).

A well-known example of an oxidation product apparently leading to disease is oxidized cholesterol in low-density lipoprotein (LDL). This is more atherogenic than native LDL, thereby implicating oxidative stress in atherosclerosis and coronary heart disease (CHD) (6).

The following is a partial list of the conditions considered to be associated with oxidative stress: an impaired immune system and increased risk of infectious disease (7); cancer (8); diabetes (both noninsulin-dependent and insulin-dependent diabetes) $(9,10)$; autoimmune conditions including rheumatoid (11) and ankylosing spondylitis (9); various respiratory diseases (12); eye disease, including cataracts (13) and retinal damage leading to age-related macular degeneration (14); Alzheimer's disease (15); and schizophrenia (16). 


\section{FRUIT, VEGETABLES AND CANCER}

The purported close association between a state of oxidative stress and disease implies that antioxidants will be protective against these same diseases. Particularly important in this regard is the strong inverse relationship seen between intake of fruit and vegetables and the risk of cancer (17) with an overall risk reduction of between 30 and 50\% (18). If these impressive benefits are a result of the intake of antioxidants, then the obvious protective substances may be vitamin $\mathrm{C}$ and the carotenoids.

Epidemiological data link vitamin $\mathrm{C}$ intake with reduced risk of several cancers, especially oral cavity, esophagus, stomach and, to a lesser extent, colon and lung $(19,20)$. Likewise, the epidemiological evidence clearly shows a strong inverse association between the intake of $\beta$ carotene and the risk of several cancers, especially lung and stomach (21). Some attention has been paid to other carotenoids. Epidemiological studies have reported that $\alpha$-carotene has an inverse association with cancer of a similar strength to that seen for $\beta$-carotene (22). Lycopene, a carotenoid present in tomatoes, has attracted much attention recently; it shows a strong inverse relationship with several types of cancer, especially prostate, lung and stomach (23). A weaker association has been described for lutein (22). Each of these substances is an antioxidant. It must be stressed. however, that "association does not prove causation." In reality, vitamin C and carotenoids may be acting merely as surrogate measures of fruit and vegetables and it is other components of these foods that prevent cancer. The crucial evidence - the gold standard - is a controlled clinical trial. But the results of three such trials provided no evidence of cancer prevention by supplements of $\beta$ carotene (24-28).

There is some evidence of protection against cancer by supplemental $\beta$-carotene based on early endpoints. One study reported significant reversal of leukoplakia, a precancerous oral lesion (29). Similarly, another study observed partial regression of precancerous changes of the stomach (30). A trial on Filipino betel nut chewers reported a reduction in numbers of buccal mucosa cells with micronuclei (31). This indicates the prevention of precancerous changes of the oral cavity.

Let us now address the question as to why trials using $\beta$-carotene failed to prevent cancer. Possibilities that have been suggested include: the wrong carotenoid was given, or it was given at the wrong dose, or for an insufficient duration, or at the wrong stage of carcinogenesis. However, another very real possibility is that antioxidants are not the common denominator between fruit, vegetables and the prevention of cancer. Other factors that may offer a partial explanation are

1. There is a strong inverse relationship between the intake of dietary fiber and colon cancer (32). There is also evidence suggestive of an inverse relationship between fiber and breast cancer (33). However, as vegetables (and, to a lesser extent, fruit) are a major source of fiber, part of this association may represent confounding by associated substances

2. Cruciferous vegetables - broccoli, cabbage, cauliflower, brussels sprouts, and others - contain phytochemicals which induce the synthesis of detoxifying enzymes and may thereby be anticarcinogenic (34). This helps explain the epidemiological evidence indicating a protective relationship between these vegetables and colon cancer (35). 


\section{FRUIT, VEGETABLES AND CHD}

Law and Morris (36) recently estimated that an increase in consumption of fruit and vegetables could potentially reduce levels of $\mathrm{CHD}$ by $15 \%$.

Although the data lack consistency, a negative association has been reported between intake of vitamin $\mathrm{C}$ and carotenoids and the risk of CHD (6). Kritchevsky et al. (37) have reported a negative relationship between intake of carotenoids with vitamin A activity and carotid artery plaques. As with cancer these associations mighl easily reflect confounding by associated substances present in fruit and vegetables. Intervention studies have indicated that supplemental $\beta$-carotene does not protect against $\mathrm{CHD}(25,27,28)$.

Fruit and vegetables are, of course, a major source of not only antioxidants but also of other dietary factors. The latter may explain why fruit and vegetables help prevent CHD. Potassium is protective against elevated blood pressure, a major risk factor for CHD $(38,39)$. In addition, evidence which has only recently emerged indicates that folate is protective against $\mathrm{CHD}$ and other cardiovascular diseases $(40,41)$. The mechanism appears to be that folate lowers the blood level of homocysteine $(42,43)$, which is a risk factor for $\mathrm{CHD}(41,44,45)$. The evidence for these associations, however, is inconsistent (46).

We cannot therefore conclude that fruit and vegetables prevent CHD because of their content of antioxidants. Indeed, Law and Morris (36) recently argued that folate and potassium fully explain the protective action of fruit and vegetables against $\mathrm{CHD}$.

\section{SELENIUM, VITAMIN E AND DISEASE}

In addition to vitamin $\mathrm{C}$ and carotenoids there are other antioxidants in food that may have anticarcinogenic action. Animal experiments have demonstrated that selenium functions as an antioxidant (47). There is much evidence from international correlation studies and from animal experiments that selenium is protective against cancer (30). Data from the Health Professionals Follow-Up Study indicate a strong inverse association between selenium status and risk of prostate cancer (48). One controlled intervention study has been carried out and this reported a dramatic $50 \%$ fall in total cancer mortality using a supplement of $200 \mu \mathrm{g} /$ day (i.e., several times greater than the RDA) (49). Clearly, this exciting observation merits further study.

Turning to vitamin $\mathrm{E}$ the epidemiological evidence is inconclusive for a protective role in cancer though this antioxidant does appear to be negatively associated with colorectal adenomas (22). In the ATBC Cancer Prevention Study a dose of $50 \mathrm{mg} /$ day apparently reduced the incidence of prostate and colorectal cancer by $36 \%$ and $16 \%$, respectively (24). Vitamin E (400 IU/day) caused partial regression of precancerous changes of the stomach (30). One interpretation of these seemingly contradictory findings is that vitamin $\mathrm{E}$ becomes anticarcinogenic only at pharmacological doses (i.e., when the intake is several times greater than the US RDA [8-10 $\mathrm{mg} / \mathrm{day}]$ ).

Evidence both from international and prospective studies has indicated that vitamin $\mathrm{E}$ intake is negatively related to the risk of $\mathrm{CHD}(6)$. In two of the prospective studies the strongest association 
was with total intake of vitamin $\mathrm{E}$ (diet plus supplements) $(50,51)$. Intervention trials, by contrast, have failed to show a protective benefit of supplemental vitamin $\mathrm{E}(36)$. Other data indicate that the vitamin reduces the susceptibility of LDL to oxidation (52-54) and this may be expected to be protective against atherosclerosis. Studies on experimental animals have also shown that vitamin $E$ can be protective against atherosclerosis (6). Taking this clearly inconclusive evidence as a whole vitamin $\mathrm{E}$ may have a mild preventive action against $\mathrm{CHD}$, especially at intakes of over $50 \mathrm{mg} /$ day.

Other work has indicated a possibly beneficial role for supplemental vitamin $\mathrm{E}$ in diabetes based on lowered serum levels of glycosylated hemoglobin and triglyceride (55). Supplemental vitamin $\mathrm{E}$ at a dose of 60-800 IU/day reportedly improves immune function in elderly subjects (56), while a single dose of $1 \mathrm{~g}$ helped prevent oxidative damage of DNA (57).

If vitamin $\mathrm{E}$ and selenium are indeed protective against disease, this has little relevance to the question of how fruit and vegetables prevent disease as these foods are a minor source of those nutrients, especially of the high doses that appear most effective.

\section{HOW IMPORTANT ARE ANTIOXIDANTS?}

The possible benefit of vitamin $C$ and $\beta$-carotene has been studied in other conditions apart from cancer and CHD. Epidemiological evidence suggests that vitamin C protects against cataracts (13), asthma (12), and a decline in pulmonary function (58). As emphasized earlier such associations must be viewed cautiously. However, in the case of vitamin $\mathbf{C}$ and asthma, there is also some supporting evidence from intervention studies (12). Supplemental doses of $\beta$-carotene and of vitamin C each help prevent oxidative damage of DNA (57,59), while $\beta$-carotenc also improves immune function (60).

Studying the relationship between antioxidant status and disease has proven to be a highly profitable line of research. It has expanded our knowledge concerning the etiology of numerous diseases and the means by which they might be prevented. But it is essential to take a balanced perspective and avoid the danger of over-enthusiasm for the potential of antioxidants.

The importance of the association between oxidative stress and disease should not be exaggerated. Halliwell et al. (3) pointed out that disease processes can give rise to oxidative stress (in addition to the reverse). Halliwell (5) also noted that: "In most human diseases oxidative stress is a secondary phenomenon, not the primary cause of the disease." Likewise, Dusinska et al. (9) caution that the role of oxidative DNA damage in carcinogenesis has not been proven and that there are many inconsistencies in the relationship. Red wine has significant antioxidant activity (61) but evidence from case-control and prospective studies indicates that it has a no greater protective association with CHD than any other type of alcoholic beverage (62).

Taking the evidence as a whole it is difficult to escape the lack of convincing evidence that places oxidative stress at the center of any disease process or gives antioxidants a major role in the prevention of disease. While many studies have shown associations between intake of antioxidants and disease risk, very few studies have provided evidence that antioxidants actually prevent any disease. Conversely, there is strong evidence that fruits and vegetables prevent cancer, CHD and possibly other diseases. We cannot at this time say how much of this, if any, is due to antioxidants and how much to nutrients and phytochemicals. 
One line of investigation that should prove profitable is intervention studies using fruit and vegetables (63). Such studies can expand our knowledge concerning the protective relationship of these foods against cancer, CHD and other diseases such as hypertension. It may be more intellectually satisfying to determine which nutrient or phytochemical is most effective in disease prevention but that approach can be hit-and-miss as we have seen with the $\beta$-carotene trials.

\section{THE POSSIBLE BENEFITS OF SUPPLEMENTS}

Should we take supplements? While we have overwhelming evidence for advising a generous intake of fruit and vegetables, the evidence is scanty and contentious that supplements of the antioxidant nutrients and phytochemicals provided by these foods (vitamin $\mathrm{C}$ and the carotenoids) will prevent disease. This confirms the conventional wisdom that the best source of nutrients and phytochemicals is food not supplements.

We must bear in mind that whole grains are also of great importance. Evidence from many casecontrol studies on cancer $(64,65)$ and a prospective study on CIID (66) indicates that a generous intake of whole grains reduces the risk of both diseases by one third. For the above reasons, therefore, it is highly unlikely that any one-a-day pill presently available will have the health-giving properties of whole foods.

However, there is some positive evidence in support of supplements. Taking the evidence as a whole, vitamin $\mathrm{E}$, which is mainly obtained from oils, may have a mild protective action against $\mathrm{CHD}$ and certain cancers. The benefit seems most likely at intakes only obtainable from supplements (typically $50-500 \mathrm{mg} /$ day). While more research is clearly needed, especially from intervention studies which look at incidence and death from $\mathrm{CHD}$ and cancer, supplementation with $50 \mathrm{mg} /$ day of vitamin E may well commend itself as a general prophylactic.

Selenium may also prove to be a potent cancer-preventive agent but this requires further study. It is essential that the dose is not excessive (maximum of $100-200 \mu \mathrm{g}$ /day) due to the risk of toxicity.

The evidence obtained from studies on vitamin $\mathrm{E}$ and selenium indicates the potential for substances which provide safe, effective and cheap means to prevent degenerative diseases and to help preserve body function well into old age.

\section{REFERENCES}

1. Halliwell B, Gutteridge JMC. Free Radicals in Biology and Medicine, 2 nd ed, Oxford: Oxford University Press, 1989.

2. Parke DV. Nutritional antioxidants and disease prevention: mechanisms of action. In: Basu TK, Temple NJ, Garg ML, eds. Antioxidants in Human Health and Disease. Wallingford, Oxon, UK: CAB International, 1999: 1-13.

3. Halliwell B, Gutteridge JM, Cross CE. Free radicals, antioxidants, and human disease: where 
are we now? J Lab Clin Med 1992; 119:598-620.

4. Halliwell B. Free radicals, antioxidants and human disease: curiosity, cause or consequence? Lancet $1994 ; 344: 721-4$.

5. Halliwell B. Antioxidants in human health and disease. Ann Rev Nutr 1996; 16:33-50.

6. Kritchevsky D, Kritchevsky SB. Antioxidants and their role in coronary heart disease prevention. In: Basu TK, Temple NJ, Garg ML, eds. Antioxidants in Human Health and Disease. Wallingford, Oxon, UK: CAB International, 1999: 151-64.

7. Bendich A. Immunological role of antioxidant vitamins. In: Basu TK, Temple NJ, Garg ML, eds. Antioxidants in Human Health and Disease. Wallingford, Oxon, UK: CAB International, 1999: 27-41.

8. Ames BN, Shigenaga MK, Hagen TM. Oxidants, antioxidants and the degenerative diseases of aging. Proc Natl Acad Sci, USA 1993; 90:7915-22.

9. Dusinska M, Lietava J, Olmedilla B, Raslova K, Southon S, Collins AR. Indicators of oxidative stress, antioxidants and human health. In: Basu TK, Temple NJ, Garg ML, eds. Antioxidants in Human Health and Disease. Wallingford, Oxon, UK: CAB International, 1999: 411-22.

10. Hannon-Fletcher $M$, Hughes $C$, O'Kane MJ, Moles KW, Barnett CR, Barnett YA. An investigation of in vivo antioxidant status and DNA damage in patients with IDDM. In: Basu TK, Temple NJ, Garg ML, eds. Antioxidants in Human Health and Disease. Wallingford, Oxon, UK: CAB International, 1999: 259-69.

11. Halliwell B. Oxygen radicals, nitric oxide and human inflammatory joint disease. Ann Rheum Dis 1995; 54:505-10.

12. Young IS, Roxborough HE, Woodside JV. Antioxidants and respiratory disease. In: Basu TK, Temple NJ, Garg ML, eds. Antioxidants in Human Health and Disease Wallingford, Oxon, UK: CAB International, 1999: 293-311.

13. Taylor A, Jacques P, Epstein E. Nutrition and the risk for cataract. In: Basu TK, Temple NJ, Garg ML, eds. Antioxidants in Human Health and Disease. Wallingford, Oxon, UK: CAB International, 1999: 271-84.

14. Nath R, Gupta A, Prasad R, Pandav SS, Thakur R. Reactive oxygen species and age-related macular degeneration. In: Basu TK, Temple NJ, Garg ML, eds. Antioxidants in Human Health and Disease. Wallingford, Oxon, UK: CAB International, 1999: 285-92

15. Martins RN, Chan CW, Waddington E, Veurink G, Laws S, Croft K, Dharmarajan AM. Betaamyloid and oxidative stress in the pathogenesis of Alzheimer's disease. In: Basu TK, Temple NJ, Garg ML, eds. Antioxidants in Human Health and Disease. Wallingford, Oxon, UK: CAB International, 1999: 367-91.

16. Reddy R, Yao JK. Schizophrenia: role of oxidative stress and essential falty acids. In. Basu TK, Temple NJ, Garg ML, eds. Antioxidants in Human Health and Disease. Wallingford, Oxon, UK: CAB International, 1999: 351-66. 
17. Steinmetz KA, Potter JD. Vegetables, fruit, and cancer prevention: A review. J Am Diet Assoc 1996; 96:1027-39.

18. Block G, Patterson BH, Subar AF. Fruit, vegetables, and cancer prevention: a review of the epidemiological evidence. Nutr Cancer 1992; 18:1-29.

19. Block G. Vitamin C and cancer prevention: the epidemiological evidence. Am J Clin Nutr 53, 270S-82S, 1991.

20. Byers $T$, Guentero N. Epidemiulogic evidence for vitamin $\mathrm{C}$ and vitamin $\mathrm{E}$ in cancer prevention. Am J Clin Nutr 1995; 62:1385S-92S.

21. Van Poppel G, Goldbohm RA. Epidemiologic evidence for $\beta$-carotene and cancer prevention Am J Clin Nutr 1995; 62:1393S-402S.

22. Greenwald P, McDonald SS. Antioxidants and the prevention of cancer. In: Basu TK, Temple NJ, Garg ML, eds. Antioxidants in Human Health and Disease. Wallingford, Oxon, UK: CAB International, 1999: 217-34.

23. Giovannucci E. Tomatoes, tomato-based products, lycopene, and cancer: Review of the epidemiological literature. J Natl Cancer Inst 1999; 91:317-32.

24. Heinonen OP, Albanes D, Virtamo J, Taylor PR, Huttenen JK, Hartman AM, Haapakoski J, Malila M, Rautalahti M, Ripatti S, Maenpaa H, Teerenhovi L, Koss L, Virolainen M, Edwards BK. Prostate cancer and supplementation with $\alpha$-tocopherol and $\beta$-carotene: incidence and mortality in a controlled trial. J Natl Cancer Inst 1998; 90:440-6.

25. Alpha-Tocopherol Carotene Cancer Prevention Study Group. The effect of vitamin E and carotene on the incidence of lung cancer and other cancers in male smokers. N Engl J Med $1994 ; 330: 1029-35$

26. Omenn GS, Goodman GE, Thornquist MD, Balmes J, Cullen MR, Glass A, Keogh JP, Meyskens FL, Valanis B, Williams JH, Barnhart S, Cherniack MG, Brodkin CA, Hammar S. Risk factors for lung cancer and for intervention effects in CARET, the $\beta$-Carotene and Retinol Efficacy Trial. J Natl Cancer Inst 1996; 88:1550-9.

27. Omenn GS, Goodman GE, Thornquist MD, Balmes J, Cullen MR, Glass A, Keogh JP, Meyskens FL, Valanis B, Williams JH, Barnhart S, Hammar S. Effects of a combination of carotene and vitamin A on lung cancer and cardiovascular disease. N Engl J Med 1996; 334:1150-5.

28. Hennekens $\mathrm{CH}$, Buring JE, Manson JE, Stampfer M, Rosner B, Cook NR, Belanger C, LaMotte F, Gaziano JM, Ridker PM, Willett W, Peto R. Lack of effect of long-term supplementation with carotene on the incidence of malignant neoplasms and cardiovascular disease. N Engl J Med 1996; 334:1145-9.

29. Garewal HS, Meyskens FL, Killen D, Reeves D, Kiersch TA, Elletson H, Strosberg A, King D, Steinbronn K. Response of oral leukoplakia to $\beta$-carotene. J Clin Oncol 1990; 8:1715-20. 
30. Bukin YV, Draudin-Krylenko VA. The role of carotene and vitamin E in the treatment of early gastric premalignant lesions: biochemical and clinical aspects. In: Basu TK, Temple NJ, Garg ML, eds. Antioxidants in Human Health and Disease. Wallingford, Oxon, UK: CAB International, 1999: 235-48.

31. Stitch HF, Stitch W, Rosin MP, Vallejera MO. Use of the micronucleus test to monitor the effect of vitamin A, beta-carotene and canthaxanthin on the buccal mucosa of betel nut/tobacco chewers. Int J Cancer 1984; 34:745-50.

32. Tiuck B, Lanca E, Greenwald P. Dietary fiber, vegetables, and colon cancer: critical review and meta-analysis of the epidemiological evidence. J Natl Cancer Inst 1990; 82:650-61.

33. Heaton KW. Dietary fiber. In: Temple NJ, Burkitt DP, eds. Western Diseases: their Dietary Prevention and Reversibility. Totowa, NJ: Humana Press, 1994: 187-208.

34. Nestle M. Broccoli sprouts in cancer prevention. Nutr Rev 1998; 56:127-30.

35. Graham S, Mettlin C. Diet and colon cancer. Am J Epidemiol 1979; 109:1-20.

36. Law MR, Morris JK. By how much does fruit and vegetable consumption lower the risk of ischaemic heart disease? Eur J Clin Nutr 1998; 52:549-56.

37. Kritchevsky SB, Tell GS, Shimakawa T, Dennis B, Li R, Kohlmeier L, Steere E, Heiss G. Provitamin A carotenoid intake and carotid artery plaques: the Atherosclerosis Risk in the Communities Study. Am J Clin Nutr 1998; 68:726-33.

38. Temple NJ. Vitamins and minerals in cancer, hypertension, and other diseases. In: Temple NJ, Burkitt DP, eds. Western Diseases: their Dietary Prevention and Reversibility. Totowa, NJ:: Humana Press, 1994: 209-35.

39. Brancati FL, Appel LJ, Seidler AJ, Whelton PK. Effect of potassium supplementation on blood pressure in African Americans on a low-potassium diet. Arch Intern Med 1996; 151:61-7.

40. Rimm ER, Willett WC, Hu FB, Sampson L, Colditz, GA, Manson JE, Hennekens C, Stampfer MJ. Folate and vitamin B6 from diet and supplements in relation to risk of coronary heart disease among women. JAMA 1998; 279:359-64.

41. Robinson K, Arheart K, Refsum H, Brattstrom L, Boers G, Ueland P, Rubba P, Palma-Reiss R, Meleady R, Daly L, Witteman J, Graham I. Low circulating folate and vitamin B6 concentrations. Risk factors for stroke, peripheral vascular disease, and coronary heart disease. Circulation 1998; 97:437-43.

42. Nygard O, Refsum, H, Ueland PM, Vollset SE. Major lifestyle determinants of plasma total homocysteine distribution: the Hordaland Study. Am J Clin Nutr 1998; 67:263-70.

43. Malinow MR, Duell PB, Hess DL, Anderson PH, Kruger WD, Phillipson BE, Gluckman RA, Block PC, Upson BM. Reduction of plasma homocyst(e)ine levels by breakfast cereal fortified with folic acid in patients with coronary heart disease. N Engl J Med 1998; 338:1009-15. 
44. Wald NJ, Watt HC, Law MR, Weir DG, McPartlin J, Scott JM. Homocysteine and ischemic heart disease. Arch Intern Med 1998; 158:862-7.

45. Welch GN, Loscalzo J. Homocysteine and atherothrombosis. N Engl J Med 1998; 338: 1042-50

46. Folsom AR, Nieto FJ, McGovern PG, Tsai MY, Malinow MR, Eckfeldt JH, Hess DL, Davis CE. Prospective study of coronary heart disease incidence in relation to fasting total homocysteine, related genetic polymorphisms, and B vitamins. The Atherosclerosis Risk in Communities (ARIC) Study. Circulation 1998; 98:204-10.

47. Vinson JA, Stella JM, Flanagan TJ. Selenium yeast is an effective in vitro and in vivo antioxidant and hypolipemic agent in normal hamsters. Nutr Res 1998; 18:735-42.

48. Yoshizawa K, Willett WC, Morris SJ, Stampfer MJ, Spiegelman D, Rimm EB, Giovannucci E. Study of prediagnostic selenium level in toenails and the risk of advanced prostate cancer. J Natl Cancer Inst 1998; 90:1219-24.

49. Clark LC, Combs GF, Turnbull BW, Slate EH, Chalker DK, Chow J, Davis LS, Glover RA, Graham GF, Gross EG, Krongrad A, Lesher JL, Park HK, Sanders BB, Smith CL, Taylor JR. Effects of selenium supplementation for cancer prevention in patients with carcinoma of the skin. JAMA 1996; 276:1957-63.

50. Rimm EB, Stampfer MJ, Ascherio A, Giovannucci E, Colditz GA, Willett WC. Vitamin E consumption and the risk of coronary heart disease in men. N Engl Med 1993; 328:1450-6.

51. Stampfer MI, Hennekens CH, Manson JE, Colditz GA, Rosner GA, Willett WC. Vitamin E consumption and the risk of coronary disease in women. N Engl J Med 1993; 328:1444-9.

52. Woodside JV, Young IS, Yarnell JWG. Fruit, vegetables and antioxidants: their role in the prevention of cardiovascular and other diseases. In: Basu TK, Temple NJ, Garg ML, eds. Antioxidants in Human Health and Disease. Wallingford, Oxon, UK: CAB International, 1999: 205-15.

53. Esterbauer H, Gebicki J, Puhl H, Jurgens G. Role of lipid peroxidation and antioxidants in oxidative modification of LDL. Free Radic Biol Med 1992; 13:341-90.

54. Iribarren C, Folsom AR, Jacobs DR, Gross MD, Belcher JD, Eckfeldt JH. Association of serum vitamin levels, LDL susceptibility to oxidation, and autoantibodies against MDA-LDL with carotid atherosclerosis: a case-control study. Arterio Thromb Vasc Biol 1997; 17:1171-7.

55. Jain SK. Oxidative stress, vitamin E and diabetes. In: Basu TK, Temple NJ, Garg ML, eds. Antioxidants in Human Health and Disease. Wallingford, Oxon, UK: CAB International, 1999: 249-57.

56. Meydani SN, Meydani M, Blumberg JB, Leka LS, Siber G, Loszewski R, Thompson C, Pedros MC, Diamond RD, Stollar BD. Vitamin E supplementation and in vivo immune response in healthy elderly subjects. JAMA 1997; 277:1380-6.

57. Panayiotidis M, Collins AR. Ex vivo assessment of lymphocyte antioxidant status using the comet assay. Free Radic Res 1997; 27:533-7. 
58. Hu G, Zhang X, Chen J, Peto R, Campbell TC, Cassano PA. Dietary vitamin C intake and lung function in rural China. Am J Epidemiol 1998; 148:594-9.

59. Duthie SJ, Ma A, Ross MA, Collins AR. Antioxidant supplementation decreases oxidative DNA damage in human lymphocytes. Cancer Res 1996; 56:1291-5.

60. Santos MS, Meydani SN, Leka L. Wu D, Fotouhi N, Meydani M, Hennekens CH, Gaziano JM. Natural killer cell activity in elderly men is enhanced by $\beta$-carotene supplementation. Am J Clin Nutr 1997; 64:772-7.

61. Nigdikar SV, Williams NR, Griffin BA, Howard AN. Consumption of red wine polyphenols reduces the susceptibility of low-density lipoproteins to oxidation in vivo. Am J Clin Nutr 1998; 68:258-65.

62. Rimm EB, Klatsky A, Grobbee D, Stampfer MJ. Review of moderate alcohol consumption and reduced risk of coronary heart disease: is the effect due to beer, wine, or spirits? BMJ 1996; 312:731-6.

63. Temple NJ. Fruit, vegetables, and cancer prevention trials. J Natl Cancer Inst (in press).

64. Jacobs DR, Marquart L, Slavin J, Kushi LH. Whole-grain intake and cancer: an expanded review and meta-analysis. Nutr Cancer 1998; 30:85-96.

65. Chatenoud L, Tavani A, La Vecchia C, Jacobs DR, Negri E, Levi F, Franceschi S. Whole grain food intake and cancer risk. Int J Cancer, 1998; 77:24-8.

66. Jacobs DR, Meyer KA, Kushi LH, Folsom AR. Whole-grain intake may reduce the risk of ischemic heart disease death in postmenopausal women: the Iowa Women's Health Study. Am J Clin Nutr 1998; 68:248-57.

Accepted for publication July 21, 1999. 